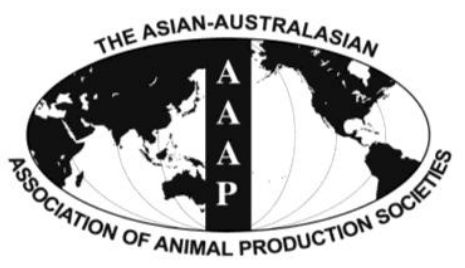

Asian-Aust. J. Anim. Sci.

Vol. 26, No. 3 : 349-357 March 2013

http://dx.doi.org/10.5713/ajas.2012.12226

www.ajas.info

pISSN 1011-2367 elSSN 1976-5517

\title{
Intake and Performance of Yearling Steers Grazing Guineagrass (Panicum maximum cv. Tanzânia) Pasture Supplemented with Different Energy Sources
}

\author{
M. C. A. Santana*, V. B. P. Euclides ${ }^{1}$, A. B. Mancio $^{2}$, S. R. Medeiros ${ }^{1}$, J. A. R. Costa and R. L. Oliveira ${ }^{3}$ \\ Department of Animal Science, Universidade Federal de Viçosa, Viçosa, MG 36571, Brazil
}

\begin{abstract}
The aim of this study was to evaluate the efficiency of supplements containing different energy sources in relation to mineral supplementation of steers grazing guineagrass (Panicum maximum cv Tanzânia) pasture, during the dry season. The experimental design was a randomized block with three treatments and four replications. The treatments consisted of a mineral supplementation and two other supplements, one based on corn seed and the other based on soybean hulls, and provided at $0.8 \%$ of body weight. Forty-eight, 12 month-old crossbred steers with an average initial body weight of $267 \mathrm{~kg}$, were assigned to twelve paddocks $(1,125 \mathrm{ha})$ of guineagrass. The animals that were fed with soybean hulls and corn seed presented a greater average daily gain (0.982 and 0.937) when compared with the mineral supplementation. Soybean hulls can be used as a satisfactory food source, replacing corn as an energy source in the supplementation of beef cattle without compromising animal performance. (Key Words: Soybean Hulls, Corn, Performance, Steers, Consumption, Dry Period)
\end{abstract}

\section{INTRODUCTION}

Beef production in Brazil is characterized by production systems based on tropical pastures. The forage production and nutritive value are satisfactory in the rainy season but are poor in the dry season due to the seasonality of forage production. Thus, it is necessary to supplement the cattle in order to meet their nutritional requirements during this period.

The use of supplements can increase feed intake and provide additional nutrients. The usual energy concentrates (maize and sorghum) are rich in non-structural carbohydrates (CNEs), whose main component is starch. However, high concentrations in the diet can result in the reduction of rumen $\mathrm{pH}$ to levels below the critical value for the action of cellulolytic bacteria and reduce the degradation of fiber (Van Soest, 1994; Stockdale and Dixon,

\footnotetext{
* Corresponding Author: M. C. A. Santana. EMATER, Goiânia GO, Brazil. Tel: +55-623201-8700, Fax: +55-6232018795, E-mail: mcaspaz@hotmail.com

${ }^{1}$ Embrapa Beef Cattle Center, Campo Grande, MS, Brazil.

${ }^{2}$ Department of Animal Science, Universidade Federal de Viçosa, Viçosa, MG, Brazil.

${ }^{3}$ Universidade Federal da Bahia, Salvador, BA, Brazil. Submitted Dec. 20, 2011; Accepted Jul. 2, 2012; Revised Sept. 7, 2012
}

1999).

The use of foods with high levels of non-starch polysaccharide compounds (PNA), such as soybean hulls, can promote the digestibility of fibre asthey do not produce lactic acid or lower the $\mathrm{pH}$ during fermentation. Thus, the use of supplements rich in PNA can help to increase the digestibility of forage, enhancing the feed intake and animal performance (Van Soest, 1994; Euclides and Medeiros, 2005). Grigsby et al. (1993) and Mendes et al. (2005) observed that animals fed diets containing soybean hulls in partial substitution of corn had a higher level of dietary fiber digestion. However, several authors (Faulkner et al., 1994; Gomes, 1998; Fisher and Mulhbach, 1999) reported no differences in the performance of cattle fed soybean hulls in place of corn.

The aim of this study was to evaluate the use of supplements with different energy sources in contrast to mineral supplementation on the performance and the feed consumption by yearling steers, during the dry season.

\section{MATERIAL AND METHODS}

The experiment was conducted at Embrapa Beef Cattle (Lat. $20^{\circ} 27^{\prime} \mathrm{S}$, Long. $54^{\circ} 37^{\prime} \mathrm{W}$ and Alt $530 \mathrm{~m}$ ), Campo Grande, MS, from July 22 to October 21, 2005. 
The experimental area was composed of twelve 1.125 ha paddocks of guineagrass pastures (Panicum maximum cv. Tanzania). These pastures were established in 2000 and have since been managed under rotational grazing with a variable stocking rate during the rainy season and a continuous and fixed stocking rate during the dry period.

During the experimental period, the rainfall, relative humidity and air temperature were recorded (Figure 1), and the average temperature and cumulative monthly rainfall were used to calculate the water balance. The storage capacity of the soil water used was $75 \mathrm{~mm}$. Forty-eight steers of three genetic groups (1/2 Angus-1/2 Nellore; Braford 1/2-1/4 Angus-Nellore; and 1/4-1/2 Brahman-1/4 Angus-1/4 Nellore) were used. They had an average age of 12 months and an average body weight of $265 \pm 22 \mathrm{~kg}$. The animals were assigned to paddocks so that the average body weight of four steers were almost the same for each paddock. All animals were identified with RFID. At the beginning of the experiment and during the experimental period, the animals were treated for endo- and ectoparasites.

The experimental design was a completely randomized block design with three treatments and four replications (paddocks). The treatments consisted of a mineral supplement (SM; control) and two other supplements, one whose energy source was based on corn (GM) and the other based on soybean hulls (CS). The proportions and chemical composition of the ingredients are listed in Table 1. The GM and CS supplements were provided daily at 9:00 and 15:00 at level of $0.8 \%$ of body weight (BW), and the mineral supplement was provided ad libitum.

The animals were weighed monthly after fasting for 16 $\mathrm{h}$ from food and water. The average daily gain was calculated as the difference in animal weight divided by the number of days between weightings.

The dry matter intake was estimated in the middle of the trial period, starting on September 1, 2005. Chromic oxide was used as an external indicator ( $10 \mathrm{~g}$ of $\mathrm{Cr}_{2} \mathrm{O}_{3}$ animal-1 d), which was packed in paper cartridges and placed directly into the rumen through a hose adapted to a plunger (introduced via the esophagus). The supply was a single daily dose for seven days at approximately 12:00 h. The feces were taken directly from the rectum of each animal on d 6 at 8:00 am, d 8 at 12:00 $\mathrm{h}$ and $\mathrm{d} 8$ at 16:00 $\mathrm{h}$, as described by Valadares Filho (2005). The feces were dried in a forced air oven at $50^{\circ} \mathrm{C}$, ground in a Willey-type mill (with a $1.0 \mathrm{~mm}$ sieve) and analyzed for the content of $\mathrm{Cr}$ in an atomic absorption spectrophotometer, as described by Williams et al. (1962). The excretion of fecal dry matter was estimated based on the ratio of the supplied quantity of the indicator and its concentration in feces, as proposed by Burns et al. (1994). The estimate of indigestible NDF was made by incubating the samples from simulated grazing, supplements, and feces for 144 h (Cochran et al., 1986; Detmann, 1999). The consumption estimates were obtained using the equation proposed by Detmann et al. (2001).

After estimating the forage intake, the replacement rate (Moore et al., 1999) was calculated as the unit varied in forage intake per unit of supplement intake: replacement rate $($ TS $)=($ IMSFs-IMSFn)/IMSs, where IMSFs $=$ herbage DM intake by steers that were supplemented (PC \%), IMSFn = herbage DM intake by steers that were not supplemented $(\mathrm{PC} \%)$, and IMSs = supplement DM intake (\% BW).

Forage samples were taken at 28-d intervals, fifteen 1 $\mathrm{m}^{2}$ areas were selected at random within each paddock, and herbage was harvested on the ground level. Each sample subsampled twice, one of was oven dried at $55^{\circ} \mathrm{C}$ (fan forced) for $72 \mathrm{~h}$, the other subsample was separated into leaf blade (leaf), stem (stem+sheath) and dead material and each fraction was dried $\left(55^{\circ} \mathrm{C}\right)$ The proportions of each separated component were expressed as a percentage of the total dry weight, and they mass were used to estimate the

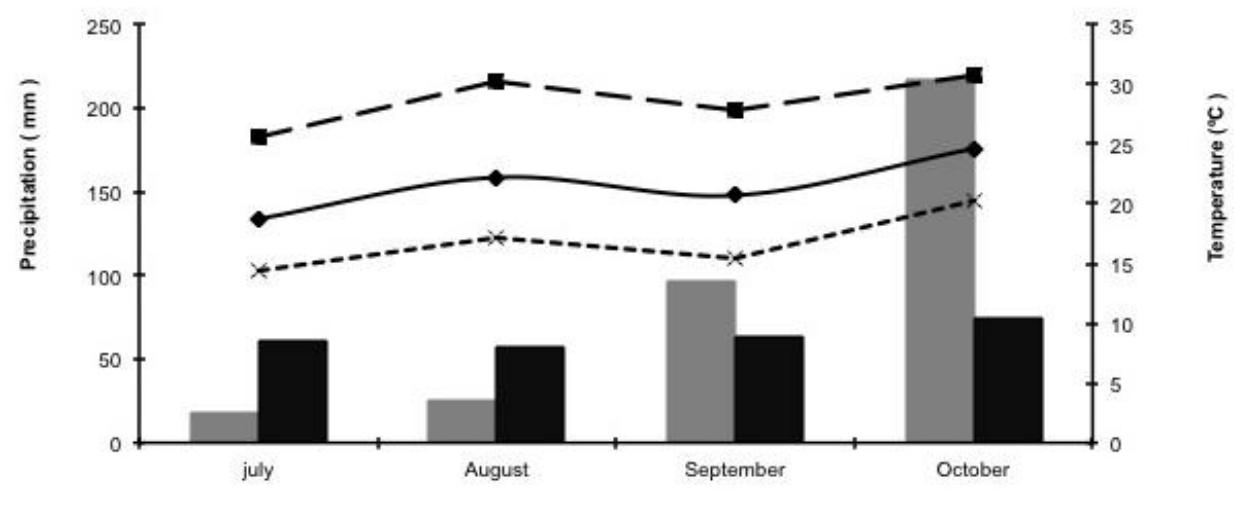

Precipitation $\longrightarrow$ Relative humidity $\rightarrow$ Average temperature $-*-$ Minimum temperature $\rightarrow$ Maximum temperature

Figure 1. Precipitation $(\mathrm{mm} / \mathrm{month})$; relative humidity $(\%)$; and minimum, average and maximum temperature $\left({ }^{\circ} \mathrm{C}\right)$ for the period from July to October 2005. 
Table 1. Percentage and chemical composition of the experimental diets

\begin{tabular}{|c|c|c|c|}
\hline \multirow{2}{*}{ Ingredients $(\%)$} & \multicolumn{3}{|c|}{ Treatment } \\
\hline & MS & $\mathrm{COS}$ & $\mathrm{SOH}$ \\
\hline Corn grain & - & 41.1 & - \\
\hline Soybean meal & - & 49.5 & 24.3 \\
\hline Soy beans & - & - & 24.3 \\
\hline Soybean hulls & - & - & 48.0 \\
\hline Limestone & & 2.5 & 2.5 \\
\hline Salt mineral ${ }^{1}$ & 100.0 & 0.8 & 0.8 \\
\hline White salt & - & 6.0 & 0.0 \\
\hline Rumensin & - & 0.06 & 0.06 \\
\hline \multicolumn{4}{|l|}{ Chemical composition of energy supplements } \\
\hline Dry matter $(\%)$ & - & 88.62 & 89.09 \\
\hline Crude protein (\% DM) & - & 31.8 & 26.5 \\
\hline Neutral detergent fiber (NDF, \% DM) & - & 11.54 & 38.23 \\
\hline $\operatorname{NDFap}^{\mathrm{a}}(\% \mathrm{DM})$ & - & 10.26 & 34.8 \\
\hline Ether extract (\% DM) & - & 3.22 & 6.37 \\
\hline Acid detergent lignin (ADL, \% DM) & - & 0.29 & 0.46 \\
\hline Mineral matters (MM, \% DM) & - & 9.43 & 7.46 \\
\hline Non-fiber carbohydrates (CNF, \% DM) & - & 41.17 & 20.89 \\
\hline Total carbohydrates (\% DM) & - & 52.71 & 59.12 \\
\hline $\operatorname{IVDM}^{\mathrm{b}}(\%)$ & - & 90.76 & 79.09 \\
\hline $\mathrm{Ca}(\%)$ & - & 0.84 & 1.04 \\
\hline $\mathrm{P}(\%)$ & - & 0.44 & 0.28 \\
\hline $\mathrm{Na}(\mathrm{ppm})$ & - & 18,661 & 2,395 \\
\hline $\operatorname{Mg}(\% \mathrm{DM})$ & - & 0.165 & 0.194 \\
\hline $\mathrm{Fe}(\mathrm{ppm})$ & - & 196.8 & 609.5 \\
\hline $\mathrm{Zn}(\mathrm{ppm})$ & - & 8,418 & 114.83 \\
\hline $\mathrm{Mn}(\mathrm{ppm})$ & - & 35.12 & 48.21 \\
\hline $\mathrm{Cu}(\mathrm{ppm})$ & - & 13.86 & 15.51 \\
\hline TDN & - & 76.96 & 75.95 \\
\hline
\end{tabular}

${ }^{1}$ Mineral composition: sodium chloride, $48.75 \%$; flowers of sulfur, 7.36; dicalcium phosphate, $39.26 \%$; Potassium iodide, $0.015 \%$; Sodium selenite, $0.008 \%$; Sulfate cobalt , $0.014 \%$; Sulfate copper, $0.69 \%$; Zinc sulfate, $3.89 \%$.

${ }^{\mathrm{a}} \mathrm{NDF}$ and ash-free protein. ${ }^{\mathrm{b}}$ In vitro DM digestibility.

relationships of the leaf:stem ratio (LSR) and the leaf:nonleaf ratio (stem+dead material; LNLR) and to estimate the mass of the leaf blade.

The supply of dry matter (OMS; kg of dry matter per $100 \mathrm{~kg}$ body weight) was calculated by dividing the dry weight by the total body weight of the animals kept in the paddock during the same period. The leaf offer (OL; $\mathrm{kg}$ of dry leaf per $100 \mathrm{~kg}$ body weight) was calculated in the same manner, considering only that component of the plant.

In each paddock, two hand plucked samples were collected each month to simulate animal grazing. These were ground to $1 \mathrm{~mm}$ and analyzed to estimate the crude protein content, neutral detergent fiber content, in vitro digestibility of organic matter using near infrared reflectance spectroscopy (NIRS) in accordance with the procedures of Marten et al. (1985), and lignin in acid detergent in accordance with the procedures of Van Soest et al. (1991).

Monthly samples of the supplements were collected, ground in a Willey-type mill to $1 \mathrm{~mm}$ and analyzed for their bromatological constituents, AOAC (1990), neutral detergent fiber and acid detergent fiber contents were evaluated (Goering and Van Soest, 1970). The neutral detergent fiber ash and protein content were determined according to the techniques described in Silva and Queiroz (2002). The in vitro dry matter concentrate was determined by the modified technique of Tilley and Terry (1963).

The level of non-fibrous carbohydrates (NFCs) in the supplements was estimated according to the formula proposed by Hall (2000): NFC $=100-(\% \mathrm{CP}+\% \mathrm{NDF}+\%$ $\mathrm{EE}+\%$ Ash). The level of estimated total digestible nutrients (TDNest) was obtained using the equations suggested by NRC (2001) according to the composition of the assessed foods: $\mathrm{TDN}=\mathrm{TDN} 1 \mathrm{X}(\%)=\square \mathrm{tdNFC}+\mathrm{tdCP}+(\mathrm{tdFA} \times 2.25)$ + tdNDF-7, where on average, metabolic fecal TDN equaled $7 ; \operatorname{tdCP}($ concentrates $)=(1-(0.4 \times \mathrm{PIDA} / \mathrm{PB})) ; \operatorname{tdFA}=(\mathrm{EE}-$ $1) \times 100 ; \operatorname{tdNDF}=0.75(\mathrm{cpNDF}-\mathrm{L}) \times(1-(\mathrm{L} / \mathrm{cpNDF}) 0.667)$; and $\mathrm{L}=$ lignin. 
The pasture characteristics were analyzed by a mathematical model containing the random effect of block and the fixed effects of supplement, period in the dry season and their interactions. For the dry matter intake, were considered the random effect of block and the fixed effects of crossbreed and supplement, and their interactions. For animal performance data was considered the random effect of block and the fixed effect of crossbreed, supplement, period of supplementation in the dry season and their interactions. All analyses were performed using the procedure "Mixed" (SAS Institute, 1996). Means were compared by the Tukey test at 5\% probability level. In the case of significant interactions, means were compared by the probability of difference (PDIFF) option of SAS and the tukey test at $5 \%$ probabbility level.

\section{RESULTS AND DISCUSSION}

Independent of supplement use, the pastures were similar regarding the mass of dry matter (MDM, p = 0.3052); leaf dry matter (ML, $p=0.2740)$; offer dry matter (ODM, $\mathrm{p}=0.7675)$; offer leaf dry matter (OL, $\mathrm{p}=0.8914)$; leaf percentage ( $\mathrm{PL}, \mathrm{p}=0.6485)$; stem percentage $(\mathrm{PS}, \mathrm{p}=$ $0.7416)$; dead material percentage (DM, $\mathrm{p}=0.5150)$; leaf:stem ratio (LSR, $p=0.9004)$; leaf:non-leaf (LNLR, $p=$ $0.8041)$; crude protein $(\mathrm{CP}, \mathrm{p}=0.8854)$; neutral detergent fiber (NDF $\mathrm{p}=0.0669)$; acid detergent lignin (ADL, $\mathrm{p}=$ $0.7512)$ and in vitro digestibility of organic matter (OMIVD, $\mathrm{p}=0.5862)$. There were no interactions ( $p>0.05)$ involving the effects of the supplement and the period during the dry season for all variables associated with the characterization of the pastures. Therefore, the differences in animal performance were the result of the supplements used.

In contrast, significant changes were observed over dry period for the forage mass and for the variables associated with the sward structure (Table 2). These changes were likely the consequence of the changing climatic conditions (Figure 1), which influenced the flow of tissue in the plants. Such a pattern of variation in morphological composition of sward herbage mass through the dry season is well documented for guineagrass cv. Tanzânia (Barbosa et al., 2007).

At the beginning of the trial period (July/August), the pasture herbage mass had a high PL, which resulted in a high ML, OL, LSR and LNLR. However, during the second period (August/September), there were increases in the PS and PM and a decrease in the PL and, consequently, decreases in the OMS, OL, LSR and LNLR (Table 2). The morphological changes in these components could be explained by the soil water deficit registered during this period (Figure 1), a condition related to leaf senescence and the death of tillers (Cano et al., 2004; Mesquita et al., 2010). Moreover, considering that the animals' diet consists mainly of leaves (Euclides, 2000; Brâncio et al., 2003; Trindade et al., 2007), a reduction in that component and increases in the PS and PDM forage mass rejected are expected.

In the third period (September/October), with the restoration of precipitation and a temperature increase (Figure 1), the reverse trend was observed: there was a decrease in the PDM and an increase in the PL and thus increases in the ML, OL, LSR and LNLR (Table 2). Decreases in the PL during the dry season and increases in early spring were also found by Euclides et al. (2007a) for grazed guineagrass.

Despite increases in the NDF and ADL in the third period (Table 2$)$, the content of IVDOM ( $p=0.3785)$ was similar in all three periods, with the average and its standard error being $65.5 \% \pm 2.1$. In addition, there was no difference between the periods for the content of CP $(p=0.4076)$, which averaged of $11.0 \% \pm 0.9$. In general, the nutritional

Table 2. Masses of dry matter (MDM) and leaves (ML), offers of dry matter (ODM) and leaves (OF), percentages of leaf (PL), stem (PS) and dead material (PDM), leaf:stem (LSR) and leaf:non-leaf ratios (LNLR), and neutral detergent fiber (NDF) and acid detergent lignin (ADL) contents, according to the periods of the dry season

\begin{tabular}{|c|c|c|c|c|c|}
\hline & \multicolumn{3}{|c|}{ Periods $^{\mathrm{a}}$} & \multirow{2}{*}{$\mathrm{SE}^{\mathrm{b}}$} & \multirow{2}{*}{$\mathrm{p}$} \\
\hline & 1 & 2 & 3 & & \\
\hline MDM (kg DM/ha) & $3,435^{\mathrm{a}}$ & $2,580^{\mathrm{b}}$ & $2,150^{\mathrm{c}}$ & 215 & 0.0012 \\
\hline ML (kg DM/ha) & $2,445^{\mathrm{a}}$ & $700^{\mathrm{c}}$ & $1,275^{\mathrm{b}}$ & 149 & 0.0001 \\
\hline ODM (kg DM/100 kg BW) & $9.3^{\mathrm{a}}$ & $8.3^{\mathrm{ab}}$ & $6.1^{\mathrm{b}}$ & 0.8 & 0.0220 \\
\hline OF (kg DM/100 kg BW) & $6.7^{\mathrm{a}}$ & $2.2^{\mathrm{b}}$ & $3.6^{\mathrm{b}}$ & 0.5 & 0.0001 \\
\hline PL $(\%)$ & $71.6^{\mathrm{a}}$ & $27.1^{\mathrm{c}}$ & $60.4^{\mathrm{b}}$ & 3.0 & 0.0001 \\
\hline PS $(\%)$ & $8.8^{\mathrm{b}}$ & $14.0^{\mathrm{a}}$ & $13.5^{\mathrm{a}}$ & 1.2 & 0.0084 \\
\hline $\operatorname{PDM}(\%)$ & $19.7^{\mathrm{b}}$ & $59.1^{\mathrm{a}}$ & $25.9^{\mathrm{b}}$ & 3.2 & 0.0001 \\
\hline LSR & $10.4^{\mathrm{a}}$ & $2.2^{\mathrm{b}}$ & $5.9^{\mathrm{b}}$ & 1.5 & 0.0038 \\
\hline LNLR & $3.1^{\mathrm{a}}$ & $0.4^{\mathrm{b}}$ & $2.6^{\mathrm{a}}$ & 0.7 & 0.0371 \\
\hline $\mathrm{NDF}(\%)$ & $68.2^{\mathrm{b}}$ & $66.6^{\mathrm{b}}$ & $71.0^{\mathrm{a}}$ & 0.7 & 0.0003 \\
\hline $\operatorname{ADL}(\%)$ & $2.7^{\mathrm{b}}$ & $2.7^{\mathrm{b}}$ & $3.8^{\mathrm{a}}$ & 0.1 & 0.0001 \\
\hline
\end{tabular}

${ }^{\mathrm{a}}$ Period 1: 7/22 to 8/23; Period 2: 8/24 to 9/21; Period 3: $9 / 22$ to $10 / 20 .{ }^{\mathrm{b}}$ Standard error.

Means followed by different letters in the same line do not differ by the Tukey test at $5 \%$ probability. 
Table 3. Consumption of dry forage (CF), total dry matter (CFS), crude protein (CPB), neutral detergent fiber (CNDF), the replacement rate of forage intake by the consumption of concentrate, initial and final body weight (BW), and average daily gain (ADG) of animals supplemented with mineral salt (MS), supplements based on corn (COS) or supplements based on soybean hulls (SOH) in Guineagrass pasture grass during the dry period

\begin{tabular}{|c|c|c|c|c|c|}
\hline \multirow{2}{*}{ Item } & \multicolumn{3}{|c|}{ Treatments } & \multirow{2}{*}{$\mathrm{SE}^{\mathrm{a}}$} & \multirow{2}{*}{$\mathrm{p}$} \\
\hline & MS & $\mathrm{COS}$ & $\mathrm{SOH}$ & & \\
\hline$\overline{\mathrm{CF}}(\mathrm{kg} / 100 \mathrm{~kg} \mathrm{BW})$ & 2.16 & 1.91 & 1.96 & 0.10 & 0.2811 \\
\hline CFS (kg/100 kg BW) & - & 2.62 & 2.68 & 0.11 & 0.3406 \\
\hline $\mathrm{CCP}(\mathrm{kg} / 100 \mathrm{~kg} \mathrm{BW})$ & $0.24^{\mathrm{b}}$ & $0.44 \mathrm{a}$ & $0.42^{\mathrm{a}}$ & 0.01 & 0.0001 \\
\hline CNDF $(\mathrm{kg} / 100 \mathrm{~kg} \mathrm{BW})$ & 1.51 & 1.41 & 1.60 & 0.07 & 0.1274 \\
\hline Substitution rate (\%) & & -0.36 & -0.28 & 0.12 & 0.6127 \\
\hline Initial BW (kg) & 269 & 263 & 270 & & \\
\hline Final BW (kg) & $311^{\mathrm{b}}$ & $344^{\mathrm{a}}$ & $356^{\mathrm{a}}$ & 10.7 & 0.0065 \\
\hline $\operatorname{ADG}\left(\mathrm{g}\right.$ animal $\left.^{-1} \mathrm{~d}\right)$ & $0.530^{\mathrm{b}}$ & $0.937^{\mathrm{a}}$ & $0.982^{\mathrm{a}}$ & 0.04 & 0.0001 \\
\hline
\end{tabular}

${ }^{\mathrm{a}}$ Standard error. Means followed by same letters in row did not differ by the Tukey test at $5 \%$ probability.

value during the experimental period was higher than that observed by Euclides et al. (2007b) for Guineagrass pasture grass during the same period.

There was no effect of supplement use on the consumption of dry forage (CF; Table 3 ). These results were similar to the values of $2.05 \mathrm{~kg}$ DM per $100 \mathrm{~kg}$ body weight (BW) and $1.9 \mathrm{~kg}$ DM per $100 \mathrm{~kg}$ of BW reported by Euclides et al. (1999) and Brâncio et al. (2003), respectively, in a Guineagrass pasture during the dry period. As the supply of concentrate was limited to $0.8 \%$ of body weight and was completely consumed, the total consumption of dry matter forage plus supplement (CFS) for the supplement based on corn (COS) had a CFS similar to the supplement based on soybean hulls ( $\mathrm{SOH}$, Table 3). This result is opposite to that observed by Van Soest (1994) and Dixon and Stockdale (1999) who reported greater dry matter intakes when foods with high levels of non-starch polysaccharides compounds were used as supplements.

Regardless of supplementation, the crude protein from the pasture was similar $(\mathrm{p}=0.2326)$; however, as the supplements contained approximately $28 \%$ CP (Table 1), the animals that received the $\mathrm{SOH}$ and GM supplements showed a higher CCP than those receiving only MS (Table 3). Deficiencies of specific nutrients can limit intake (Minson, 1990). Therefore, the animals were supplemented with mineral salt ad libitum, and it can be assumed that consumption was not limited by macro- and microelements. In addition, a $\mathrm{CP}$ content of less than $7 \%$ can drastically reduce the intake (Minson, 1990). However, the forage intake contained approximately $11 \% \mathrm{CP}$ (Table 3 ); thus, the protein was not the limiting factor in consumption.

The intake of NDF for animals receiving different supplements was similar (Table 3). A result in line with results reported elsewhere for animals grazing guineagrass pasture grass during the dry season (Euclides et al., 1999; Gontijo Neto et al., 2006). The control mechanism for forage intake was likely the physical distension of the reticulo-rumen, as suggested by Mertens (1994), when the $\mathrm{NDF}$ intake was greater than $12 \mathrm{~g}$ per $\mathrm{kg}$ of PS; thus, consumption is limited by the filling of the rumen.

In addition to the NDF, the herbage mass and sward structure may be important in controlling the intake of forage by animals grazing on Guineagrass (Euclides et al., 1999; Brâncio et al., 2003; Gontijo Neto et al., 2006). These conditions were evaluated (Table 2) in the second period when the forage intake ODM was within the range considered to be optimal, which according to Hodgson (1990), is a supply of forage from three to four times the daily needs of the animal. Therefore, the dry matter supply has not limited forage intake. However, during this same period, the pastures had a lower PL, LSR and LNLR (Table 2), suggesting that the sward structure was unfavorable to selective grazing and likely could have been another factor limiting the intake of forage. In the Carvalho et al. (2008) study, the presence of stems and dead material on the grazing horizon limited the depth of the bite, and it is common in this condition to observe an increase in time per bite and bite rate reduction (Palhano et al., 2007; Trindade et al., 2007) and an increase in daily grazing time (Difante et al., 2009).

Although the supplement intake did not significantly influence the consumption of herbage, there was a rate of substitution (Table 3). According to Dixon and Stockdale (1999) and Moore et al. (1999), a negative substitution coefficient indicates that the supplement reduced the intake of forage. According to the assumptions made by Moore et al. (1999) to explain the substitution effect, two factors could explain the reduction in dietary forage: a TDN:CP less than 7, which in this experiment was 5.37, and a voluntary consumption of forage without supplementation greater than $1.75 \%$ of $\mathrm{PV}$, which in this study was $2.16 \%$ of BW. It is important to adequately assess the effects of substitution, to accurately predict the effect the rate of substitution, and to increase the stocking rate of pastures, 
which represents an alternative auxiliary management strategy during the dry period when the herbage mass is generally low.

Animal performance was not influenced by genetic group ( $\mathrm{p}=0.4118$ ), and there was no interaction ( $\mathrm{p}=$ 0.5162) between the effects of genetic group and supplementation. All animals gained weight, whereas those supplemented with concentrate had higher gains than the non-supplemented animals (Table 3). For both sources of energy, the observed gains were similar to those obtained by Brito et al. (2008), who supplemented Canchin steers on palisadegrass pasture during the dry season with concentrates balanced for different levels of production. However, there was no difference in the average daily gain (ADG) of the animals supplemented with $\mathrm{COS}$ or $\mathrm{SOH}$ (Table 3). The lack of an effect from the energy source in the supplement composition on animal performance was also observed by Garcia et al. (2004), Agulhon et al. (2005) and Moraes et al. (2006).

The low response obtained with the mineral supplement was due to the limitation of not meeting the nutritional requirements of the animals (Lana, 2002). However, the result was close to that found by Euclides 2001 in Guineagrass pasture and Garcia (2005) in pastures of $B$. decumbens, who observed, respectively, gains of 530 and $410 \mathrm{~g} / \mathrm{animal} / \mathrm{d}$ for animals receiving $0.2 \%$ of the protein salt.

An interaction was observed $(p=0.0083)$ between the effect of the supplement and the period (month of dry season) for the ADG. Animals receiving only MS gained less weight than those receiving $\mathrm{COS}$ or $\mathrm{SOH}$, except in the third period, when the ADG was similar for the different supplementations (Table 4). During the second period, animals supplemented with MS and SOH had lower a ADG than in other periods because the animals supplemented with COS had a similar ADG in all three periods (Table 4). There were no differences in the CP content and IVDOM throughout the dry season, and the NDF and ADL were similar to value in the first period and were above the value from the third period, which likely indicates that the limited animal production in the second period was not due to nutrition-related factors associated with the feeding behavior of the animals. In this context, the low supplies of
Table 4. Average daily gain $\left(\mathrm{kg}\right.$ animal $\left.{ }^{-1} \mathrm{~d}\right)$ of animals receiving different types of supplements, according to the periods in the dry season

\begin{tabular}{lcccc}
\hline & \multicolumn{3}{c}{ Treatments } & \multirow{2}{*}{ Mean } \\
\cline { 2 - 4 } & $\mathrm{MS}$ & $\mathrm{COS}$ & $\mathrm{SOH}$ & \\
\hline Period 1 & $0.608^{\mathrm{Ab}}$ & $0.936^{\mathrm{Aa}}$ & $1.096^{\mathrm{Aa}}$ & 0.880 \\
Period 2 & $0.133^{\mathrm{Bb}}$ & $0.845^{\mathrm{Aa}}$ & $0.736^{\mathrm{Ba}}$ & 0.570 \\
Period 3 & $0.870^{\mathrm{Aa}}$ & $1.033^{\mathrm{Aa}}$ & $1.120^{\mathrm{Aa}}$ & 1.008 \\
\hline
\end{tabular}

${ }^{a}$ Period 1: 7/22 to 8/23; Period 2: 8/24 to 9/21; Period 3: 9/22 to 10/22. Means followed by the same letters, uppercase and lowercase letters in the row in the column do not differ by the Tukey test at $5 \%$ probability.

leaf and sward structures, characterized by a low PL, LSR and LNLR (Table 2), were the limiting factors for forage intake by the grazing animals, as discussed earlier, and consequently, animal performance.

However, despite the lower nutritional value (Table 2), the animals had an increase in ADG from the second to third periods (Table 4), which can be explained by the increase in the PL in the same period; this increase resulted in a higher ML and a sward structure more conducive to grazing animals (Table 2) due to the regrowth of pastures following increases in precipitation amount and temperature (Figure 1).

The estimates of weight gain as a function of metabolizable energy intake, calculated (crossbred males with $340 \mathrm{~kg} \mathrm{BW}$ ) according to the CNCPS (2003), were similar to the observed weight gains (Tables 4 and 5).

However, there was an overestimation of the values of weight gain due to the consumption of metabolizable COS and $\mathrm{SOH}$ protein supplements of 60 and 44\%, respectively. This result shows that energy was the most limiting nutrient for weight gain and that it is possible that the protein contained in the COS and SOH supplements was not utilized in its entirety to provide increased ADG, as estimated by CNCPS (Table 5). Thus, supplements with the lowest amount of protein could have been used under these conditions without diminishing performance.

The estimated consumption and performance calculated using the mathematical models developed for the different conditions, such as the CNCPS, still need to be adapted to tropical systems, such as those in Brazil. These models, in general, underestimate consumption (Jorge et al., 1997;

Table 5. Consumption of metabolizable energy (ME, Mcal/d) and metabolizable protein (MP, g/d) for maintenance, weight and total gain $^{1}$

\begin{tabular}{|c|c|c|c|c|c|c|}
\hline \multirow{2}{*}{ Item } & \multicolumn{2}{|c|}{ SM } & \multicolumn{2}{|c|}{ GM } & \multicolumn{2}{|c|}{$\mathrm{CS}$} \\
\hline & $\mathrm{ME}$ & MP & $\mathrm{ME}$ & MP & ME & MP \\
\hline Maintenance & 8.97 & 335 & 8.71 & 366 & 8.73 & 387 \\
\hline Gain & 4.59 & 140 & 10.91 & 309 & 11.51 & 322 \\
\hline Total & 13.7 & 475 & 19.62 & 675 & 20.24 & 709 \\
\hline Estimated gain $(\mathrm{kg} / \mathrm{d})$ & 0.43 & 0.49 & 1.00 & 1.54 & 1.05 & 1.45 \\
\hline
\end{tabular}

${ }^{1}$ Estimate of weight gain according to the supplements used.

Estimated values of the CNCPS 5.0. 
Cappelle et al., 2001; Gesualdi Jr. et al., 2005); however, these underestimates are lower when the animals are crossbred (Machado Neto et al., 2010).

The animals supplemented with $\mathrm{COS}$ or $\mathrm{SOH}$ concentrates had a feed conversion of 2.52 and 2.48, respectively. For both sources of energy, the results indicate that the observed conversions used in conjunction with the pasture were able to provide higher gains than the value of 3.54 reported by Garcia (2005), with a supplemental energy /protein of $0.8 \%$.

As discussed, other studies have been performed with cows and calves using soybean hulls in the diet (Miron et al., 2004; Garcia, 2005; Pedroso et al., 2007), and the data from this study demonstrate the feasibility of replacing the usual concentrates in cattle feed, such as corn, with the hulls of soybeans.

\section{CONCLUSIONS}

The use of soybean hulls in place of corn as a supplemented source of energy did not increase the dry matter intake of Guineagrass during the dry period when both were provided based on a $0.8 \%$ body weight to promote the substitution effect.

The choice of corn or soybeans depends on the price and availability on the market, as there is no difference in consumption and animal performance.

\section{ACKNOWLEDGEMENTS}

The work was supported by the Embrapa Beef Cattle Center and thanks the Coordenação de Aperfeiçoamento de Pessoal de Nível Superior (CAPES, Brazil) for providing the financial support with scholarship to the corresponding author.

\section{REFERENCES}

Agulhon, R. A., C. C. Jobim, A. F. Branco and M. Calixto Júnior. 2005. Fontes energéticas e níveis de suplementação para vacas em pastagem de capim-Marandu (Brachiaria brizantha Hochst ex. A. Rich Stapf) no inverno. Rev. Bras. Zootec. pp. 34:151158.

Association of Official Analytical Chemists (AOAC). 1990. Official methods of analysis. 15. ed. Washington DC, USA. p. 1.

Barbosa, R. A., D. Nascimento Junior, V. P. B. Euclides, S. C. Da silva, A. H. Zimmer and R. A. A. Torres Junior. 2007. CapimTanzânia submetidos a combinações entre intensidade e freqüência de pastejo. Pesq. Agropec. Bras. pp. 42:329-340.

Brâncio, P. A., D. Nascimento Junior, V. P. B. Euclides, D. M. da Fonseca, R. G. de Almeida, M. C. M. Macedo and R. A. Barbosa. 2003. Avaliação de três cultivares de Panicum maximum Jacq. sob pastejo: composição da dieta, consumo de matéria seca e ganho de peso animal. Rev. Bras. Zootec. pp.
32:1037-1044.

Brito, R. M., A. A. M. Sampaio, A. R. M. Fernandes, K. T. Resende, W. Henrique and R. R. Tullio. 2008. Desempenho de bezerros em pastagem de capim-Marandu recebendo suplementação com concentrados balanceados para diferentes níveis de produção. Rev. Bras. Zootec. pp. 37:1641-1649.

Burns, J. C., K. R. Pond, D. S. Fisher. 1994. Measurament of forage intake. In: Forage quality, evaluation and utilization (Ed. G. C. Fahey Junior). Madison: America Society of Agronomy, pp. 494-531.

Cano, C. C. P., U. Cecato, M. W. do Canto, A. B. Rodrigues, C. C. Jobim, A. M. Rodrigues, S. Galbeiro and W. G. Nascimento. 2004. Produção de forragem do capim-Tanzânia (Panicum maximum Jacq. cv. Tanzânia-1) pastejado em diferentes alturas. Rev. Bras. Zootec. pp. 33:1949-1958.

Capelle, E. R., S. C. Valadares Filho and J. F. C. Silva. 2001. Estimativas do consumo e do ganho de peso de bovinos, em condições brasileiras. Rev. Bras. Zootec. pp. 30:659-1957.

Carvalho, P. C. F., H. L. Gonda, M. H. Wade, J. C. Mezzalira, M. F. do Amaral, E. N. Gonçalves, D. T. do Santos, L. Nadin and C. H. E. C. Poli. 2008. Características estruturais do pasto e o consumo de forragem: o quê pastar, quanto pastar e como mover para encontrar o pasto. In: Manejo estratégico da pastagem, 4, 2008. Viçosa. Anais. Viçosa: UFV, p. 101-130.

Cochran, R. C., D. C. Adams, J. D. Wallace and M. L. Galyean. 1986. Predicting digestibility of different diets with internal markers: evaluation of four potential markers. J. Anim. Sci. pp. 63:1476-483

CNCPS. Version 5.0. The net carbohydrate and protein system for evaluating herd nutrition and nutrient excretion, Model Documentation. Cornell: Cornell University, Department of Animal Science, 2003. p. 292.

Detmann, E. 1999. Cromo e constituintes da forragem como indicadores, consumo e parâmetros ruminais em novilhos mestiços, suplementados durante o período das águas. Viçosa, MG. Universidade Federal de Viçosa. 1999. p. 103. Dissertação de Mestrado em Zootecnia. Universidade Federal de Viçosa.

Detmann, E., M. F. Paulino, J. T. Zervoudakis, S. C. Valadares Filho, R. F. Euclydes, R. P. Lana and D. S. Queiroz. 2001. Cromo e indicadores internos na estimação do consumo de novilhos mestiços, suplementados, a pasto. Rev. Bras. Zootec. pp. 30:1600-1609.

Difante, G. S., V. P. B. Euclides, D. Nascimento Júnior, S. C. da Silva, R. A. de A. Torres Jr. and D. O. L. Sarmento. 2009. Ingestive behaviour, herbage intake and grazing efficiency of beef cattle steers on tanzânia guineagrass subjected to rotational stocking managements. Rev. Bras. Zootec. pp. 38:1001-1008.

Dixon, R. M. and C. R. Stockdale. 1999. Associative effects between forages and grains: Consequences for feed utilization. Aust. J. Agric. Res. pp. 50:757-774.

Euclides, V. P. B. 2000. Alternativas para intensificação da produção de carne bovina em pastagem. Campo Grande, MS: Embrapa Gado de Corte, p. 65.

Euclides, V. P. B. 2001. Produção intensiva de carne bovina em pasto. Simpósio de produção de gado de corte, 2, Viçosa -MG, Anais. SIMCORTE Viçosa -UFV, pp. 55-82. 
Euclides, V. P. B., F. P. Costa, M. C. M. Macedo, R. Flores and M. P. Oliveira. 2007a. Eficiência biológica e econômica de pasto de capim-Tanzânia adubado com nitrogênio no final do verão. Pesq. Agropec. Bras. pp. 42:1345-1355.

Euclides, V. P. B., M. C. M. Macedo, A. H. Zimmer, R. N. Medeiros and M. P. Oliveira. 2007b. Características do pasto de capim-Tanzânia adubado com nitrogênio no final do verão. Pesq. Agropec. Bras. pp. 42:1189-1198.

Euclides, V. P. B. and S. R. Medeiros. 2005. Suplementação animal em pastagens e seu impacto na utilização da pastagem. In: simpósio sobre manejo da pastagem, 22, 2005, Piracicaba. Anais. Piracicaba:FEALQ, 33-70.

Euclides, V. P. B., L. R. L. S. Thiago, M. C. M. Macedo and M. P. Oliveira. 1999. Consumo voluntário de forragem de três cultivares de Panicum maximum sob pastejo. Rev. Bras. Zootec. pp. 28:1177-1185.

Faulkner, D. B., D. F. Hummel, D. D. Buskirk, L. L. Berger, D. F. Parrett and G. F. Cmarik. 1994. Performance and nutrient metabolism by nursing calves supplemented with limited or unlimited corn or soyhulls. J. Anim. Sci. pp. 72:470-477.

Fisher, V. and P. R. F. Mühlbach. 1999. Substituição do grão de milho por casca de soja no desempenho de novilhas de corte confinadas. Pesquisa Agropecuária Gaúcha, pp. 5:143- 148.

Garcia, J. C. R. Alcalde, M. A. Zambom, E. N. Martins, C. C. Jobim, S. R. D. F. Andrade and M. F. Pereira. 2004. Desempenho de novilhos em crescimento em pastagens de Brachiaria decumbens suplementados com diferentes fontes energéticas no período da seca e transição seca-águas. Rev. Bras. Zootec. pp. 33:2140-2150, (Suppl. 2).

Garcia, J. 2005. Suplementação para novilhos em pastagens de capim braquiária nos períodos de seca e de transição secaáguas. Maringá. Universidade Estadual do Maringá. 2005. p. 170. Tese (Doutorado em Zootecnia).

Gesualdi Jr., A., A. C. Queiroz, F. D. Resende. R. P. Lana, A. C. L. S. Gesualdi, G. F. Alleoni, E. Edenio Detmann, A. G. Razook and L. A. Figueiredo. 2005. Validação dos sistemas VIÇOSA, CNCPS e NRC para formulação de dietas para bovinos Nelore e Caracu, não-castrados, selecionados em condições brasileiras. Rev. Bras. Zootec. pp. 34:996-1004.

Goering, G. K. and P. J. Van Soest. 1970. Forage fiber analysis (apparatus, reagents, procedures and some applications). Washington, DC, USA. USDA Agr. Handbook n. 379.

Gomes, I. P. O. 1998. Substituição do milho pela casca de soja em dietas com diferentes proporções de volumoso:concentrado para bovinos em confinamento. Jaboticabal: Universidade Estadual Paulista, 1998. 84p. Tese (Doutorado em Produção Animal) - Universidade Estadual Paulista.

Gontijo Neto, M. M., V. P. B Euclides, D. Nascimento Junior, L. F. Miranda, D. M. Fonseca and M. P. de Oliveira. 2006. Consumo e tempo diário de pastejo por novilhos Nelore em pastagem de capim-Tanzânia sob diferentes ofertas de forragem. Rev. Bras. Zootec. pp. 35:60-66.

Grigsby, K. N., M. S. Kerley, J. A. Paterson and J. C. Weigel. 1993. Combinations of starch and digestible fiber in supplements for steers consuming a low-quality bromegrass hay diet. J. Anim. Sci. pp. 71:1057-1064.

Hall, M. B. 2000. Calculation of non-structural carbohydrate content of feeds that contain non-protein nitrogen. University of Florida, p. A-25 (Bulletin 339, April, 2000).

Hodgson, J. 1990. Grazing management: science into practice. New York: Longman Handbooks in Agriculture, p. 200.

Jorge, A. M., C. A. A. Fontes, J. E. Soares, J. A. Freitas, L. R. R. Rodriguez, A. C. Queiroz and F. D. Resende. 1997. Características quantitativas da carcaça de bovinos e bubalinos abatidos em diferentes estágios de maturidade. Rev. Bras. Zootec. pp. 26:1039-1047.

Lana, R. P. 2002. Sistema de suplementação alimentar para bovinos de corte em pastejo. Simulação. Rev. Bras. Zootec. pp. 31:223-231.

Machado Neto, O. R., M. M. Ladeira, T. M. Gonçalves, L. S. Lopes, D. M. Oliveira and M. S. Bassi. 2010. Feed intake and prediction assessments using the NRC, CNCPS and BRCORTE systems in Nellore and Red Norte steers finished in feedlot. Rev. Bras. Zootec. pp. 39:394-401.

Marten, G. C., J. S. Shenk and F. E. Barton. 1985. Near infrared reflectance spectroscopy (NIRS): analysis of forage quality. Washington: USDA, p. 110. (Agriculture Handbook, 643).

Mendes, A. R., J. M. B. Ezequiel, R. L. Galati, A. L. Bocchi, M. A. A. Queiroz and J. V. Feitosa. 2005. Intake, total and partial digestibility of diets with sunflower meal and three energy sources in confined steers. Rev. Bras. Zootec. 34:679-691.

Mertens, D. R. 1994. Regulation of forage intake. In: Forage quality, evaluation and utilization (Ed. D. C. Fahey Jr.). Madison: American Society of Agronomy, pp. 450-492.

Mesquita, P., S. C. Da Silva, A. J. Paiva, F. O. Caminha, L. E. R. Pereira, V. D. Guarda and D. Nascimento Júnior. 2010. Structural characteristics of marandu palisadegrass swards subjected to continuous stocking and contrasting rhythms of growth. Sci. Agric. pp. 67:23-30.

Minson, D. J. 1990. Forage in ruminant nutrition. Academic Press: New York, p. 483.

Miron, J., E. Yosef, M. Nikbachat, A. Zenou, E. Maltz, I, Halachmi and D. Ben-Ghedalia. 2004. Feeding behavior and performance of dairy cows fed pelleted nonroughage fiber byproducts. J. Dairy Sci. pp. 87:1372-1379.

Moore, J. E., M. H. Brant, W. E. Kunkle and D. I. Hopkins. 1999. Effects of supplementation on voluntary forage intake, diet digestibility, and animal performance. J. Anim. Sci. pp. 77 (Suppl. 2):122-135.

Moraes, E. H. B. K., M. F. Paulino, J. T. Zervoudakis, S. C. Valadares Filho, L. S. Cabral, E. Detmann, R. F. D. Valadares and K. A. K. Moraes. 2006. Associação de diferentes fontes energéticas e protéicas em suplementos múltiplos na recria de novilhos mestiços sob pastejo no período da seca. Rev. Bras. Zootec. pp. 35:914-920.

National Research Council (NRC). 2001. Nutrient of requirements of dairy cattle. 7. ed. Washington, DC, USA: National Academic Press, p. 362.

Palhano, A. L., P. C. F. Carvalho, J. R. Dittrich, A. Moraes, S. C. Silva and A. L. G. Monteiro. 2007. Características do processo de ingestão de forragem por novilhas holandesas em pastagem de capim-mombaça. Rev. Bras. Zootec. pp. 36:1014-1021.

Pedroso, A. M., F. A. P. Santos, C. M. M. Bittar, A. Vaz Pires, J. C. Martinez. 2007. Substituição do milho moído por casca de soja na ração de vacas leiteiras em confinamento. Rev. Bras. Zootec. pp. 36:1651-1657. 
SAS Institute. 1996. User Software: changes and enhancements through release. Cary: SAS Institute. (Version 6.11).

Silva, D. J. and A. C. Queiroz. 2002. Análise de alimentos: métodos químicos e biológicos. 3a Edição. Viçosa:UFV, Imp. Univ. p. 165.

Tilley, J. M. A. and R. A. Terry. 1963. A two-stage technique for the in vitro digestion of forage crops. Journal of British Grassland Society, Aberystwyth, pp. 18:104-111.

Trindade, J. K., S. C. da Silva, S. J. Souza Júnior, A. A. Giacomini, C. V. Zeferino, V. D. Guarda and P. C. de F. Carvalho. 2007. Composição morfológica da forragem consumida por bovinos de corte durante o rebaixamento do capim-Marandu submetido a estratégias de pastejo rotativo. Pesq. Agropec. Bras. pp. 42:883-890.
Valadares Filho, S. C. 2005. Desafios metodológicos para determinação das exigências de bovinos de corte no Brasil. Reunião Anual Da Sociedade Brasileira De Zootecnia, 42, Goiânia. "Anais"...Goiania:SBZ, Palestra Nutrição de Ruminantes.

Van Soest, P. J., J. B. Robertson and B. A. Lewis. 1991. Methods for dietary fiber, neutral detergent fiber, and nonstarch polysaccharides in relation to animal nutrition. J. Dairy Sci. pp 74:3583-3597.

Van Soest, P. J. 1994. Nutritional ecology of the ruminant. 2.ed. Ithaca: Cornell University, p. 476.

Williams, C. H., D. J. David and O. Ismaa. 1962. The determination of chromic oxide in faeces samples by atomic absortion spectrophotometry. J. Agric. Sci. pp. 59:381-385. 